University of Nebraska - Lincoln

DigitalCommons@University of Nebraska - Lincoln

Biochemistry -- Faculty Publications

Biochemistry, Department of

$2-2004$

\title{
Tissue-specific expression and developmental regulation of cytochrome b561 genes in Arabidopsis thaliana and Raphanus sativus
}

\author{
Wim Verelst \\ University of Antwerp, verelst@mpiz-koeln.mpg.de \\ Jyoti Kapila \\ University of Antwerp \\ Janice De Almeida Engler \\ University of Gent \\ Julie M. Stone \\ University of Nebraska-Lincoln, jstone2@unl.edu \\ Roland Caubergs \\ University of Antwerp \\ See next page for additional authors
}

Follow this and additional works at: https://digitalcommons.unl.edu/biochemfacpub

Part of the Biochemistry, Biophysics, and Structural Biology Commons

Verelst, Wim; Kapila, Jyoti; Engler, Janice De Almeida; Stone, Julie M.; Caubergs, Roland; and Asard, Han, "Tissue-specific expression and developmental regulation of cytochrome b561 genes in Arabidopsis thaliana and Raphanus sativus" (2004). Biochemistry -- Faculty Publications. 90.

https://digitalcommons.unl.edu/biochemfacpub/90

This Article is brought to you for free and open access by the Biochemistry, Department of at DigitalCommons@University of Nebraska - Lincoln. It has been accepted for inclusion in Biochemistry -- Faculty Publications by an authorized administrator of DigitalCommons@University of Nebraska - Lincoln. 
Authors

Wim Verelst, Jyoti Kapila, Janice De Almeida Engler, Julie M. Stone, Roland Caubergs, and Han Asard 
Published in Physiologia Plantarum 120:2 (February 2004), pp. 312-318; doi: 10.1111/j.0031-9317.2004.0235.x

Copyright @ 2004 Physiologia Plantarum; published by Blackwell Publishing. Used by permission.

Submitted February 20, 2003; revised June 4, 2003; published online: January 6, 2004.

\title{
Tissue-specific expression and developmental regulation of cytochrome b561 genes in Arabidopsis thaliana and Raphanus sativus
}

\author{
Wim Verelst, ${ }^{1}$ Jyoti Kapila, ${ }_{1}^{1}$ Janice De Almeida Engler, ${ }^{2}$ Julie M. Stone, ${ }^{3}$ \\ Roland Caubergs, ${ }^{1}$ and Han Asard ${ }^{3}$ \\ 1. Laboratory of Plant Physiology, University of Antwerp, Groenenborgerlaan 171, B-2020 Antwerp, Belgium \\ 2. Laboratory of Plant Genetics, University of Gent-VIB, K.L. Ledeganckstraat 35, B-9000 Gent, Belgium \\ 3. Department of Biochemistry, Plant Science Initiative, Beadle Center, University of Nebraska - Lincoln, Lincoln, NE 68588-0664, USA \\ Corresponding author - Wim Verelst. Present address: Max Planck Institute for Plant Breeding Research, Department of Molecular Plant Genetics, \\ Carl-von-Linné-Weg 10, D-50829 Cologne, Germany; e-mail verelst@mpiz-koeln.mpg.de
}

\begin{abstract}
Ascorbate (Asc) is an essential molecule in many aspects of development and stress responses in plants and animals. Cytochromes $b 561$ (cyts b561) are tightly coupled to Asc homeostasis. These proteins are found in mammalian tissues, where they are involved in the regeneration of Asc, serving the synthesis of catecholamine neurotransmitters, and in intestinal iron reduction. Plant genomes encode homologous membrane-associated, Asc-reducible cyts $b 561$. The expression of these proteins in plants, however, has so far not been studied. We have now examined the expression of two Arabidopsis thaliana cyt b561-encoding genes - Artb561-1 and Artb561-2 - using relative-quantitative RT-PCR and in situ hybridization (ISH) techniques. The genes show overlapping and distinct tissue- and organ-specific expression patterns. Transcripts of both genes are found in leaf epidermal cells, and expression seems to correlate with leaf maturation and cessation of cell elongation. Both genes are also expressed in the epidermal cell layer of stems and roots in the L1 layer of the shoot apex, in the vascular system of leaves, stems and roots, and in the root pericycle. In addition, Artb561-1 is expressed in the root cap, whereas Artb561-2 mRNA is found in the epidermis of lateral roots, in the root meristem, and in unfertilized ovules. These observations provide important information for the elucidation of the physiological function of cyts $b 561$ in plants.
\end{abstract}

Abbreviations: Asc - ascorbate; cyt(s) b561 - cytochrome(s) b561; DHA - dehydro ascorbate; ISH - in situ hybridization; MDHA monodehydro ascorbate

\section{Introduction}

Ascorbate (Asc) plays a prominent role in a large number of cellular processes, as a major component in maintaining redox homeostasis. Apart from its function as an antioxidant, it acts as a cofactor for several metabolic enzymes (Arrigoni and De Tullio 2000). As a consequence of these processes, the pool of reduced Asc molecules becomes depleted. The hydrophilic nature of Asc prevents it from diffusing freely through biological membranes. Therefore, subcellular compartments that cannot synthesize Asc require mechanisms for replenishing reduced Asc molecules. This can be achieved by either trans-membrane transport of the molecule itself (Horemans et al. 2000a, 2000b), by trans-membrane transport of electrons, using oxidized Asc (dehydro ascorbate, DHA) or monodehydro ascorbate
(MDHA) as electron acceptors (Asard et al. 1992, Horemans et al. 1994), or by a combination of both mechanisms. One protein known to replenish reduced Asc in a mammalian subcellular compartment is the chromaffin granule cytochrome b561 (cyt b561). This protein is responsible for the transfer of electrons into specialized chromaffin granule vesicles, where catecholamine neurotransmitters are synthesized by an Asc-dependent enzyme (Wakefield et al. 1986, Njus et al. 1987).

A family of membrane proteins with sequence homology to the chromaffin granule cyt $b 561$, likely to play an important role in plant cellular Asc metabolism, has only recently been identified (Asard et al. 2001). The conservation of structural features between the putative plant and animal cyt $b 561$ protein sequences is striking (Asard et al. 2001). The overall amino acid identity between human 
chromaffin granule cyt $b 561$ and the proteins encoded by the A. thaliana Artb561-1 and Artb561-2 genes is 36\% and $35 \%$, respectively. Conserved features include six predicted transmembrane helices, four His residues likely to be involved in heme ligation, and a predicted binding site for MDHA (Asard et al. 2001). A putative binding site for Asc (Okuyama et al. 1998) is not as well conserved among plant cyts b561 (Verelst and Asard 2003). At least one member of this family of plant proteins is plasma membrane localized and has been extensively characterized at the biochemical level (Asard et al. 1998, 2000, 2001).

The bovine adrenal chromaffin cyt $b 561$ has been purified (Perin et al. 1988, Tsubaki et al. 1997), and recent attempts to purify the corresponding protein from plants have been met with some success (Trost et al. 2000, Asard et al. 2001, Bérczi et al. 2001). All available information on plant cyt $b 561$ has been obtained through biochemical studies and sequence comparisons with the animal system. Although most biochemical work has been performed on purified plasma membranes of bean hypocotyls (Phaseolus vulgaris L.), the presence of cyt $b 561$ has been reported in a variety of organs from a large number of vascular plants (Asard et al. 1998, 2001). However, the physiological function of the protein in plants remains unknown. The mammalian chromaffin cyt $b 561$ shuttles electrons across the chromaffin granule membrane, from cytosolic Asc to intravesicular MDHA, thereby replenishing the pool of reduced Asc molecules (Wakefield et al. 1986, Njus et al. 1987, 2001). In vitro studies on bean hypocotyl plasma membrane vesicles have shown that the plant cyt $b 561$ is also capable of transmembrane electron transport from Asc to MDHA and ferricyanide (Asard et al. 1992, Horemans et al. 1994). These experiments indicate that plant plasma membrane cyt b561 could shuttle electrons between intracellular Asc and an extracellular acceptor, similar to the mode of action of the chromaffin cyt $b 561$ (Asard et al. 1998). Therefore, the plasma membrane cyt $b 561$ in plants may be capable of regenerating Asc in the apoplast using electrons from cytosolic Asc. It may thus be involved in the physiological actions of Asc in the extracellular space (Asard et al. 2001).

Cyt $b 561$ research has advanced by the recent identification of additional cyt $b 561$ homologues in animals. A ferric reductase in the plasma membrane of duodenal brush border cells was found to be highly homologous to the chromaffin granule cyt $b 561$ (McKie et al. 2001). The presence of multiple cyts $b 561$ supports the hypothesis that cyts $b 561$ may occur in different subcellular locations in different tissues, carrying out specialized functions.

Based on similarities to the animal cyt $b 561$ protein sequences, a number of putative cyt b561-encoding genes have been identified in dicots and monocots (Asard et al. 2001, Verelst and Asard 2003). As in mammals, more than one cyt $b 561$ homologue is present in most plant species where cyt $b 561$ genes have been identified. The occurrence of different isoforms of the cyt $b 561$ protein in plants also points to potentially different functions for these proteins in various tissues. Moreover, there is evidence for plant cyts $b 561$ to reside in multiple subcellular compartments, as indicated by sucrose gradient centrifugation analyses of cauliflower, bean and mung bean membranes (Asard et al. 1987, Scagliarini et al. 1998).

Using relative-quantitative RT-PCR, we studied the expression patterns of two putative Arabidopsis thaliana cyt b561 encoding genes (Artb561-1 and Artb561-2, TAIR accession numbers At4g25570 and At5g38630, respectively) at the organ level in A. thaliana. In addition, in situ hybridization analyses (ISH) were used to examine the expression patterns of both genes in more detail, at the tissue level in A. thaliana and Raphanus sativus (radish) sections. While all previous studies on cyt $b 561$ in plants yielded information on biochemical properties at the membrane level, these experiments are the first to provide information at the whole plant level. These results may contribute to our understanding of the physiological functions of cyt $b 561$ in plants, by promoting the formulation of working hypotheses that can be the basis for future studies.

\section{Materials and methods}

\section{Plant material and growth conditions}

A. thaliana L. cv. Columbia Col-0 and R. sativus L. seeds (bought from a local market) were surface sterilized and sown on K1 germination medium (Valvekens et al. 1988). Petri dishes were placed under growth chamber conditions ( $60 \%$ humidity, $22^{\circ} \mathrm{C}, 80 \mu \mathrm{E} \mathrm{m}^{-2} \mathrm{~s}^{-1}$ ) with a light regime of $16 \mathrm{~h}$ of light and $8 \mathrm{~h}$ of darkness. A. thaliana seedlings were collected 7 days after germination, and radish roots and shoot apices 12 days after germination. A. thaliana plants were also grown in soil, under the same growth conditions as sterile-grown plants, and after 4-6 weeks flowers and siliques were collected from these plants for ISH.

A. thaliana roots used for RNA isolation were grown in liquid cultures following the procedure of the Meyerowitz Laboratory (http://www.caltech.edu/meyerowitz), and collected 20 days after germination.

\section{Probe preparation}

Using EST clones 170N15T7 (accession number R65413) and ATTS1779 (accession number Z26702) as templates, the ESTs of Artb561-1 and Artb561-2, respectively, were amplified by PCR, using SP6 and T7 primers. The PCR products of, respectively, 927 and $678 \mathrm{bp}$ were purified by gel extraction and used as templates for in vitro transcription, using an SP6/T7 Transcription Kit (Roche Diagnostics, Mannheim, Germany) and [a- $\left.{ }^{35} \mathrm{~S}\right]-\mathrm{UTP}$ (Amersham, Roosendaal, the Netherlands). Sense and antisense radiolabeled riboprobes of both genes were synthesized and hydrolyzed to an average length of 300 nucleotides as described by de Almeida Engler et al. (2001), and column-purified using 'Bio-Spin 30 Chromatography Columns' (Bio-Rad, Hercules, CA, USA). The quality and length of the transcripts 
was checked on a denaturing agarose gel (de Almeida Engler et al. 2001).

\section{In situ hybridization (ISH)}

ISH was essentially performed as described by de Almeida Engler et al. (2001). Plant material was fixed in $2.5 \%$ glutaraldehyde in $0.1 \mathrm{M}$ cacodylate buffer, $\mathrm{pH} 7.0$, and subsequently embedded in paraffin as described by de Almeida Engler et al. (2001). A. thaliana and R. sativus tissue sections were hybridized with sense or antisense ${ }^{35}$ S-UTP labeled RNA probes of the Artb561-1 and Artb561-2 genes. For each slide $15 \times 10^{6} \mathrm{cpm}$ of [a- ${ }^{35} \mathrm{~S}$ ]-UTP-labeled RNA-probe were used for hybridization. Exposure times varied. Images were taken with a digital Axiocam (Zeiss) under standard dark and bright field optics.

\section{Relative-quantitative RT-PCR}

Total RNA was isolated from 100 to $300 \mathrm{mg}$ frozen A. thaliana tissues (seedlings, leaves, flowers, roots) using TriPure Isolation Reagent (Roche Diagnostics, Mannheim, Germany), following the manufacturer's instructions. The concentration of total RNA was quantified spectrophotometrically at $260 \mathrm{~nm}$. About $3 \mu \mathrm{g}$ of this RNA was used for cDNA synthesis with a 'First Strand cDNA Synthesis

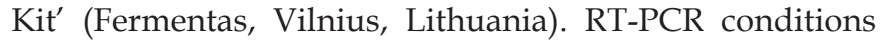
were optimized for both Artb561-1 and Artb561-2 genes, using $150 \mathrm{ng}$ of cDNA and gene-specific primers overlapping intron regions. The manufacturer's instructions were followed, and care was taken that the PCR amplification reactions were stopped in the linear range, to allow reliable quantification of the amplicons. For quantification, Universal 18S rRNA primers and competimers (QuantumRNA 18S Internal Standards; Ambion, Austin, TX, USA) were used in a ratio of one to nine, as determined in trial experiments (according to the kit's manual). RT-PCR bands were visualized in agarose gels using ethidium bromide. After scanning, band intensities were quantified using OptiQuant Image Analysis Software (Packard, Meriden, CT, USA).

\section{Results}

\section{Relative-quantitative RT-PCR analyses}

Relative-quantitative RT-PCR was used to examine the expression of Artb561-1 and Artb561-2 mRNA in different A. thaliana organs. We tested the expression of both genes in young seedlings (11 days after germination (DAG)), in roots (from liquid cultures, $20 \mathrm{DAG}$ ), young and mature (fully expanded) leaves (both from plants at 25, 30, 47 and 65 DAG), flower buds, unfertilized flowers and fertilized flowers (from plants $65 \mathrm{DAG}$ ). At least three independent samples were tested for each organ type. Levels of $18 \mathrm{~S}$ rRNA were used as an internal standard. The amplification of this abundant transcript was suppressed using Ambion's competimer technology (Ambion), so that the amount of $18 \mathrm{~S}$ amplicon in RT-PCR was of the same order of magnitude as that of the Artb561-1 and Artb561-2 amplicons. Expression levels were expressed relative to that of $18 \mathrm{~S}$ rRNA. To compare the mRNA levels of the cytb561 genes in different organs, the average amount of cytb561 mRNA in seedlings was arbitrarily set to 1 , and the levels in other organs were expressed relative to this value (Figure 1). It was not possible to make an absolute quantitative comparison between the two genes studied in these experiments, since the RT-PCR method is only relative-quantitative, and different amounts of PCR cycles were used for optimal amplification of both transcripts.

For both genes the mRNA levels in young leaves were comparable to those in seedlings $(1.09 \pm 0.48$ and $0.82 \pm 0.30$, respectively). In mature leaves the levels were slightly higher than in seedlings, but statistically not significantly different $(1.54 \pm 0.27$ and $1.32 \pm 0.39$, respectively). Plant age (DAG) did not affect the results for leaves, because similar values were obtained for leaves of comparable developmental stages collected from plants 25, 30, 47 and 65 DAG (data not shown).

In flower buds and unfertilized flowers, the Artb561-1 transcript levels $(0.28 \pm 0.06$ and $0.27 \pm 0.05)$ were significantly lower than in seedlings, whereas the levels of Artb561-2 mRNA in these samples were comparable to those in seedlings $(1.19 \pm 0.21$ in flower buds and $1.32 \pm 0.16$ in unfertilized flowers). In fertilized flowers that were starting to form seeds, levels of both genes were very low: the Artb561-1 and Artb561-2 transcript levels were $0.08 \pm 0.02$ and $0.43 \pm 0.13$, respectively. For both genes the reduction in expression in fertilized flowers was about $70 \%$, when compared to flower buds or unfertilized flowers. The expression in flowers thus suggested developmental regulation of both genes. There was also a pronounced organ-specificity, especially apparent in roots as compared to other organs. In roots, the expression levels of both genes were significantly higher than in seedlings ( $3.50 \pm 0.36$ and $5.78 \pm 0.76$ ). However, we can not fully exclude an effect of growth conditions (liquid culture versus soil-grown plants) on the Artb561-1 and -2 expression levels in roots. Our data suggest a differential expression of these two genes.

\section{In situ hybridization}

ISH was used to investigate the expression patterns of the two putative cyt $b 561$ encoding genes in tissue sections of A. thaliana and its closely related species $R$. sativus (radish). The $A$. thaliana and $R$. sativus genomes are very similar (Martinez et al. 1992), and radish tissues have the advantage of being considerably larger than $A$. thaliana, which allows more refined analysis of the expression patterns. Control hybridization with sense probes gave no significant background signal, and therefore only results obtained with antisense probes are presented here. 


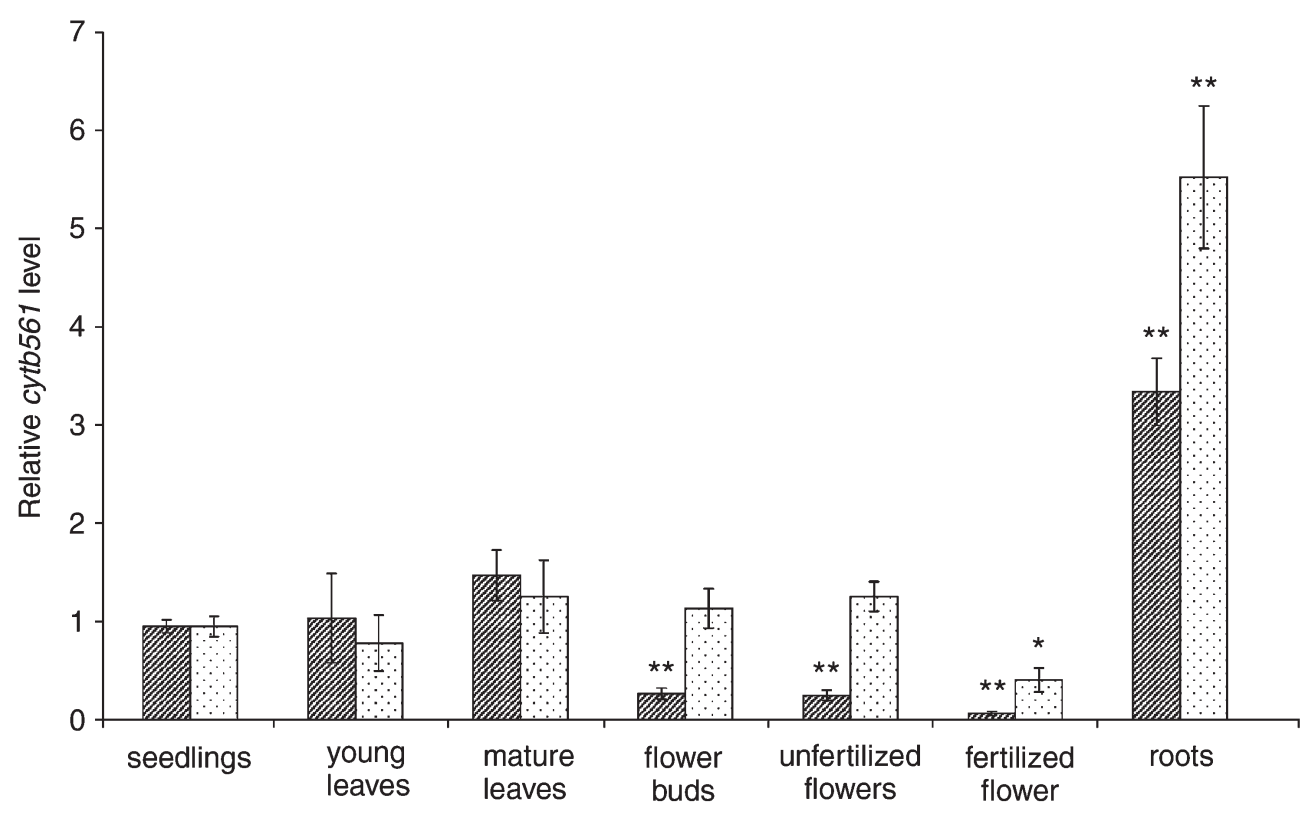

Figure 1. Relative mRNA expression levels of two $A$. thaliana genes encoding cyts b561, Artb561-1 (dashed bars) and Artb561-2 (dotted bars) in A. thaliana organs, as determined by relative-quantitative RT-PCR analysis. Amounts of cytb561 mRNA are expressed relative to $18 \mathrm{~S}$ rRNA levels (ratio cytb561/18S rRNA). The expression level in seedlings is chosen as reference, and levels from all other organs are expressed relative to the former. Values represent average expression levels relative to seedlings, \pm se $(n=3-10)$. The age of the plants used for RNA extraction was 11 DAG for seedlings, 25, 30, 47 and 65 DAG for both young and mature (fully expanded) leaves, 65 DAG for flower buds and flowers, and 20 DAG for roots. For leaves, averages of samples from plants of all different ages are shown. The level of significance for samples in which the mRNA level is significantly different from that in seedlings, as found in a $t$-test, is marked as $\left(^{*}\right)$ for $\alpha=0.01$ and $\left({ }^{* *}\right)$ for $\alpha=0.001$.
In the vegetative aerial parts of radish and $A$. thaliana seedlings, both genes Artb561-1 and -2 had identical expression patterns. In the shoot apical meristem of radish, Artb561-1 and -2 were expressed in the L1 layer of the shoot apex, in the epidermis of leaf primordia and young leaves, and in vascular bundles (Figures 2A \& 2B, respectively). Interestingly, a gradient of expression was observed in the epidermis of maturing leaves, with high levels at the base and diminishing towards the leaf tip. This points to developmental control of Artb561-1 and -2 expression in that tissue. A detailed transverse section through a maturing radish leaf confirmed high-level Artb561-1 expression in vascular bundles, with a weaker expression in the epidermis (Figure 2C). In stems, both genes were expressed in the vascular cylinder and also weakly in the epidermis (Figure 2D). The observations made in radish sections were confirmed in A. thaliana tissues. Figures $2 \mathrm{E} \& 2 \mathrm{~F}$ show the expression of Artb561-1 and -2, respectively, in A. thaliana seedlings. The epidermal patterns were visible, although sections from radish gave us better results. The expression in the L1 layer of the shoot apical meristem was apparent for Artb561-2 in A. thaliana (Figure 2F), but not for Artb561-1, as the shoot apex was not present in this section. However, comparison to radish strongly suggested that Artb561-1 was also expressed in the L1 layer of the A. thaliana shoot apex.

In radish roots, the expression patterns of both genes varied depending on the developmental stage of the tissues, comparable to the situation in leaves. More mature tissues, such as the differentiation zone, showed a strong hybridization signal of the Artb561-1 probe in the pericy- cle (Figure $2 \mathrm{G}$ ), and to a lesser extent in the vascular tissue and in the epidermis. In a younger region of the root, the elongation zone, transcripts corresponding to Artb561-1 were similarly detected in the pericycle, vascular tissue and epidermis, and expression was also observed in the cortex (Figure 2H). Similar localizations were obtained for Artb561-2 in the elongation and differentiation zones of roots (data not shown). Figure 2I shows a cross section through the differentiation zone of an A. thaliana root, in which Artb561-1 was expressed in the pericycle and in the epidermis, but not in the cortex. Again, this was consistent with the observations made in radish.

Whereas all observations presented thus far showed identical expression patterns for both genes, there were also some striking differences, namely in lateral roots, the root meristematic region and flowers. Radish lateral roots showed weak or no expression of the Artb561-1 gene (Figure 2J), whereas Artb561-2 mRNA could be detected strongly in the epidermal cell layer (Figure 2K). These differences could also be observed in A. thaliana lateral roots (Figure 2L for Artb561-2). This not only confirmed that the probes used in these experiments were hybridizing with two different genes in radish, it also suggested that these genes were most likely the Artb561-1 and -2 orthologues.

At the root tip, Artb561-1 was strongly expressed in the lateral part of the root cap and in the epidermis, whereas no expression could be seen in the meristematic tissue (Figure 2M). In contrast, Artb561-2 was strongly expressed in the cortical region of the root tip, which mainly consists of elongating cells, but not in the root cap (Figure $2 \mathrm{~N}$ ). Strong expression of Artb561-2 in the root meristematic 

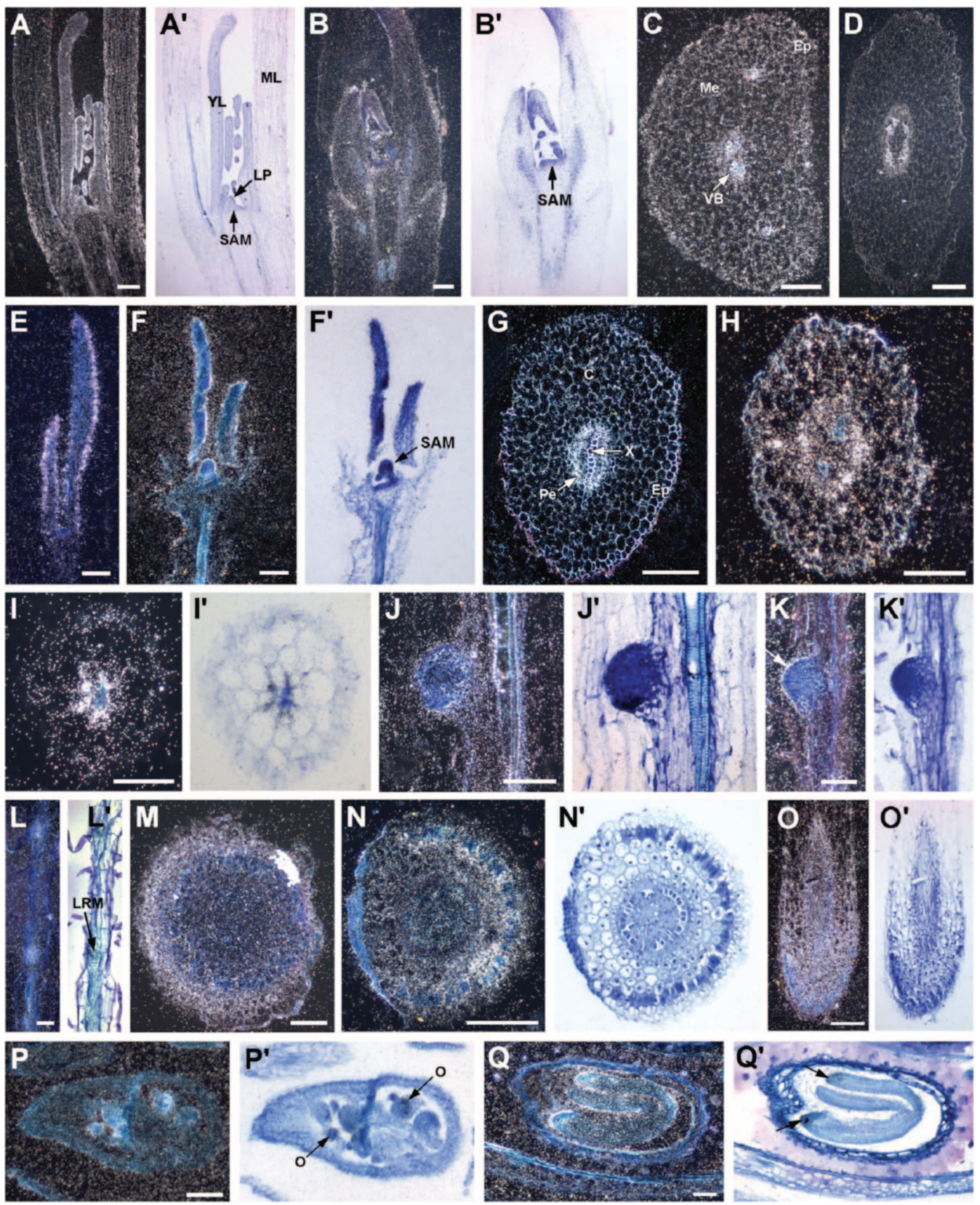

Figure 2. In situ hybridization with Artb561-1 and Artb561-2 antisense probes in R. sativus (A, B, C, D, G, H, J, K, M, N, O) and A. thaliana (E, F, I, L, $\mathrm{P}, \mathrm{Q})$ tissue sections, detected by autoradiography. For most pictures both dark and bright field images are shown (the latter with prime). The hybridization signal is seen as white dots in dark field and as black dots in bright field optics. (A) Artb561-1 expression in a radish shoot apex showing hybridization signal in the epidermis of leaf primordia (LP), young leaves (YL), maturing leaves (ML), and in the L1 layer of the shoot apical meristem (SAM); (B) Artb561-2 expression in a radish shoot apex showing a similar but weaker signal in the epidermis as in (A); (C) Transverse section of a radish leaf, showing Artb561-1 transcripts in the epidermal cell layer (Ep) and in the vascular bundles (VB), but not in the mesophyll (Me); (D) Transverse section through a radish stem, showing Artb561-2 expression in the vascular cylinder; (E) and (F) Expression of Artb561-1 and Artb561-2, respectively, in the leaf epidermis and L1 layer of A. thaliana seedlings; $(\mathrm{G})$ Transverse section through the differentiation zone of a radish root hybridized with the Artb561-1 antisense probe, showing signal in the pericycle cell layer $(\mathrm{Pe}) ; \mathrm{X}=\mathrm{xylem}, \mathrm{Ep}=\mathrm{epidermis}$; $(\mathrm{H})$ Transverse section through the elongation zone of a radish root, showing Artb561-1 expression in pericycle, vascular cylinder, epidermis and cortex; a similar pattern was observed for Artb561-2 (data not shown); (I) Artb561-1 expression in the pericycle of an A. thaliana root, confirming the pattern seen in radish; (J) Longitudinal section of an emerging radish lateral root showing Artb561-1 expression in the pericycle, but not in the lateral root; (K) Similar view for Artb561-2, showing expression in the epidermis of the emerging lateral root; (L) A. thaliana root with emerging lateral roots, expressing Artb561-2 (LRM: lateral root meristem); (M) Transverse section through a radish root meristem hybridized with Artb561-1, showing expression in the lateral part of the root cap, and in the epidermis; $(\mathrm{N})$ Transverse section through the root elongation zone, where Artb561-2 is expressed in all expanding tissues, but primarily in the cortex; $(\mathrm{O})$ Longitudinal section through a radish root meristem, showing expression of Artb561-2 in the meristem; (P) Ovary of an A. thaliana flower, expressing Artb561-2 in unfertilized ovules. Arrows point to examples of unfertilized ovules; $(\mathrm{Q})$ Mature embryo of $A$. thaliana with Artb561-2 expression in the root tip and mainly in the tips of the cotyledons. Bars in A and $\mathrm{B}=200 \mu \mathrm{m}$; in C, D, E, F, G, H, J, K, N, O, P and $\mathrm{Q}=100 \mu \mathrm{m}$; in I, L and $\mathrm{M}=50 \mu \mathrm{m}$. 
tissue could be easily observed in a longitudinal section (Figure 2O).

In A. thaliana flowers, no clear hybridization signal could be detected for the Artb561-1 gene (data not shown). In contrast, Artb561-2 was highly expressed in unfertilized ovules, whereas the signal in other parts of flowers was insignificant (Figure 2P). In heart-shaped embryos, a homogenous weak expression was observed for both genes (data not shown), whereas in mature A. thaliana embryos, both Artb561-1 and Artb561-2 were expressed primarily in the epidermis, cotyledon tips, and root tip (Figure 2Q for Artb561-2).

\section{Discussion}

Despite the importance of Asc in various aspects of plant development and stress responses, many of the key players regulating Asc homeostasis are unknown (Pastori and Foyer 2002). Components known to support Asc recycling in animals and plants include the chromaffin granule cyt $b 561$, thioredoxins, protein disulphide isomerase, and various Asc and DHA transporters (Njus et al. 1987, Wells et al. 1990, May et al. 1997, Rumsey and Levine 1998, Horemans et al. 2000a, 2000b, Patel et al. 2001).

In this paper, we present expression analyses of two A. thaliana genes encoding cyt $b 561$ proteins (Artb561-1 and Artb561-2), potentially involved in Asc recycling in plants. While the expression patterns of these two genes were similar in most organs, there were notable differences, suggesting that they support distinct physiological functions in plants. RT-PCR was used to assess expression at the organ level (Figure 1), after attempts to detect Artb561-1 transcripts by Northern blot using total RNA isolated from $A$. thaliana tissues had failed. Perhaps this was due to expression in a very restricted group of cells, which was supported by the in situ hybridization experiments. ISH demonstrated that these genes are expressed in the shoot apex, in leaves, stems, roots and inflorescences. However, expression was restricted to certain tissues: the epidermis, vascular tissue, pericycle, root cortex, root meristem and ovules.

In addition to this observed tissue-specific expression, the genes were developmentally regulated. Transcripts of both genes were detected in the epidermal cell layer of mature embryos (Figure 2Q). This expression pattern continued throughout seedling development, with highest levels of epidermal expression in leaf primordia, emerging leaves and root meristems. The L1 layer of the shoot apical meristem, which gives rise to the epidermis, strongly expressed Artb561-1 and Artb561-2 (Figures 2A \& 2B). In young leaves, transcripts were observed throughout the entire epidermis, whereas in maturing leaves a gradient of expression was seen, with the expression diminishing towards the tip (Figure 2A). This is consistent with acropetal cell differentiation in leaves (Van Lijsebettens and Clarke 1998). Similar observations were made in the root epidermis, where expression decreased with increasing distance from the root tip (for example, expression was lower in the differentiation zone than in the elongation zone; Fig- ures $2 \mathrm{G} \& 2 \mathrm{H}$, respectively). Therefore, in epidermal cells of both leaves and roots, expression levels of both genes decreased upon cell differentiation.

Developmental regulation of Artb561-1 and Artb561-2 was also observed in flowers. RT-PCR analysis showed a dramatic reduction in expression levels following fertilization (Figure 1). This was consistent with the ISH results showing that Artb561-2 had a particularly high expression in unfertilized ovules compared with fertilized ovules (Figure 2P). The hybridization signal in other floral parts was insignificant, suggesting that the observed decrease in Artb561-2 mRNA following fertilization may have been solely accounted for by a decrease in ovule-specific expression of this gene.

Although the overall expression patterns of these two genes were similar, there were also some important differences. At the root tip, Artb561-1 transcripts were mainly present in the epidermis and lateral root cap (Figure 2M), whereas Artb561-2 mRNA was detected throughout the root meristem (Figures $2 \mathrm{~N} \& 2 \mathrm{O}$ ). Emerging lateral roots did not express Artb561-1 (Figure 2J), whereas they highly expressed Artb561-2, primarily in the epidermis (Figure 2K). This differential expression indicates that the two genes analyzed may support different physiological functions, and/or have a different subcellular localization. This would resemble the situation in mammals, where two cyts $b 561$ are reported to have a different subcellular localization and possibly a different function: in chromaffin tissue, a cyt $b 561$ is present in the membrane of an intracellular granule (Wakefield et al. 1986), while in the duodenal brush border another cyt $b 561$ protein is situated in the plasma membrane (McKie et al. 2001).

It should be noted that we only report on the expression patterns of two cyt b561 encoding genes in plants, but that two more homologous genes have been identified (Artb561-3 and -4, TAIR accession numbers At1g14730 and At1g26100, respectively). The expression patterns of these other cyts b561 are not known. We are currently investigating the subcellular localization and expression patterns of all known A. thaliana cyts b561, to elucidate the roles of these proteins in plant physiology.

Acknowledgements - The authors kindly thank Prof. Gilbert Engler (RUG, Ghent, Belgium) for valuable advice, and Ruth De Groodt and Marleen Brunain (RUG, Ghent, Belgium) for technical assistance in the ISH procedures, Rebecca Verbanck (RUG, Ghent, Belgium) for art work, Prof. Yves Guisez, Dr. Nele Horemans, Dr. Marcel Jansen and Dr. Kris Vissenberg (UA, Antwerp, Belgium) for interesting discussions and for critically reading the manuscript, and Jan Neefs (UA, Antwerp, Belgium) for taking care of soil-grown Arabidopsis plants. This research was supported by grants from the Fund for Scientific Research (FWO) and the University of Antwerp; W.V. is Research Assistant of the Fund for Scientific Research, Flanders (Belgium) (FWO). A contribution of the University of Nebraska Agricultural Research Division, Lincoln, NE 68583, USA. Journal Series no. 13822. The published version of this paper was edited for Physiologia Plantarum by C. H. Foyer. 


\section{References}

de Almeida Engler J, De Groodt R, Van Montagu M, Engler G (2001) In situ hybridization to mRNA of Arabidopsis tissue sections. Meth Enzymol 23: 325-334

Arrigoni O, De Tullio MC (2000) The role of ascorbic acid in cell metabolism: between gene-directed functions and unpredictable chemical reactions. Plant Physiol 157: 481-488

Asard H, Caubergs RJ, Renders D, DeGreef JA (1987) Duroquinonestimulated NADH oxidase and $b$-type cytochromes in the plasma membrane of cauliflower and mung beans. Plant Sci 53: 109-119

Asard H, Horemans N, Caubergs RJ (1992) Transmembrane electron transport in ascorbate-loaded plasma membrane vesicles from higher plants involves a $b$-type cytochrome. FEBS Lett 306: 143-146

Asard H, Horemans N, Preger V, Trost P (1998) Plasma membrane $b$-type cytochromes. In: Asard H, Bérczi A, Caubergs RJ (eds.) Plasma Membrane Redox Systems and Their Role in Biological Stress and Disease. Kluwer, Dordrecht, The Netherlands, pp 1-31

Asard H, Kapila J, Verelst W, Bérczi A (2001) Higher-plant plasma membrane cytochrome $b_{561}$ : A protein in search of a function. Protoplasma 217: 77-93

Asard H, Terol-Alcayde J, Preger V, Del-Favero J, Verelst W, Sparla F, Pérez-Alonso M, Trost P (2000) Arabidopsis thaliana sequence analysis confirms the presence of cyt $b-561$ in plants: Evidence for a novel protein family. Plant Physiol Biochem 38: 905-912

Bérczi A, Lüthje S, Asard H (2001) b-Type cytochromes in plasma membranes of Phaseolus vulgaris hypocotyls, Arabidopsis thaliana and Zea mays roots. Protoplasma 217: 50-55

Horemans N, Asard H, Caubergs RJ (1994) The role of ascorbate free radical as an electron acceptor to cytochrome $b$ mediated trans-plasma membrane electron transport in higher plants. Plant Physiol 104: 1455-1458

Horemans N, Foyer C, Asard H (2000a) Transport and action of ascorbate at the plant plasma membrane. Trends Plant Sci 5: 263-267

Horemans N, Foyer C, Potters G, Asard H (2000b) Ascorbate function and associated transport systems. Plant Physiol Biochem 38: 531-540

Martinez MC, Jørgensen J-E, Lawton MA, Lamb CJ, Doerner PW (1992) Spatial pattern of $c d c 2$ expression in relation to meristem activity and cell proliferation during plant development. Proc Natl Acad Sci USA 89: 7360-7364

May J, Mendiretta S, Hill KE, Burk RF (1997) Reduction of dehydroascorbate to ascorbate by the selenoenzyme thioredoxin reductase. J Biol Chem 272: 22607-22610

McKie AT, Barrow D, Latunde-Dada GO, Rolfs A, Sager G, Mudaly E, Mudaly M, Richardson C, Barlow D, Bomford A, Peters TJ, Raja KB, Shirali S, Hediger MA, Farzaneh F, Simpson RJ (2001) An iron-regulated ferric reductase associated with the absorption of dietary iron. Science 291: 1755-1759
Njus D, Kelley PM, Harnadek GJ, Pacquing YV (1987) Mechanism of ascorbic acid regeneration mediated by cytochrome $b_{561}$. Ann NY Acad Sci 493: 108-119

Njus D, Wigle M, Kelley PM, Kipp BH, Schlegel HB (2001) Mechanism of ascorbic acid oxidation by cytochrome b561. Biochemistry 40: 11905-11911

Okuyama E, Yamamoto R, Ichikawa Y, Tsubaki M (1998) Structural basis for the electron transfer across the chromaffin vesicle membranes catalyzed by cytochrome $b 561$ : Analyses of DNA nucleotide sequences and visible absorption spectra. Biochim Biophys Acta 1383: 269-278

Pastori GM, Foyer CH (2002) Common components, networks, and pathways of cross-tolerance to stress. The central role of 'Redox' and abscisic acid-mediated controls. Plant Physiol 129: 460-468

Patel M, McIntosh L, Bliss T, Ho D, Sapolsky R (2001) Interactions among ascorbate, dehydroascorbate and glucose transport in cultured hippocampal neurons and glia. Brain Res 916: 127-135

Perín MS, Fried VA, Slaughter CA, Südhof TC (1988) The structure of cytochrome b561, a secretory vesicle-specific electron transport protein. EMBO J 7: 2697-2703

Rumsey SC, Levine M (1998) Absorption, transport, and disposition of ascorbic acid in humans. J Nutr Biochem 9: 116-130

Scagliarini S, Rotino L, Bäurle I, Pupíllo P, Asard H, Trost P (1998) Purification of the ascorbate reducible $b$-type cytochrome of the plasma membrane of etiolated bean seedlings. Protoplasma 205: 66-73

Trost P, Bérczi A, Sparla F, Sponza G, Marzadori B, Asard H, Pupillo P (2000) Purification of cytochrome $b-561$ from bean hypocotyl plasma membrane: evidence for the presence of two heme centres. Biochim Biophys Acta 1468: 1-5

Tsubaki M, Nakayama M, Okuyama E, Ichikawa Y, Hori H (1997) Existence of two heme B centers in cytochrome $b 561$ from bovine adrenal chromaffin vesicles as revealed by a new purification procedure and EPR spectroscopy. J Biol Chem 272: 23206-23210

Valvekens D, Van Montagu M, Van Lijsebettens M (1988) Agrobacterium tumefaciens mediated transformation of Arabidopsis thaliana root explants by using kanamycin selection. Proc Natl Acad Sci USA 85: 5536-5540

Van Lijsebettens M, Clarke J (1998) Leaf development in Arabidopsis. Plant Physiol Biochem 36: 47-60

Verelst W, Asard H (2003) A phylogenetic study of cytochrome $b 561$ proteins. Genome Biol 4: R38

Wakefield LM, Cass AEG, Radda GK (1986) Functional coupling between enzymes of the chromaffin granule membrane. J Biol Chem 261: 9739-9745

Wells WW, Xu DP, Yang YF, Rocque PA (1990) Mammalian thioltransferase (glutaredoxin) and protein disulfide isomerase have dehydroascorbate reductase activity. J Biol Chem 265: 15361-15364 